\title{
STUDYING THE MINARETS AND DOMES IN IMAMZADEHS OF DAMAVAND, TEHRAN PROVINCE
}

\author{
Atieh Youzbashi \\ Master of Visual Communication, Faculty of Arts, Shahed University, Tehran, Iran \\ Atiehyouzbashi@yahoo.com \\ Parviz Eghbali \\ Assistant Professor of Faculty of Art, Shahed University, Tehran city, Iran \\ eghbali@shahed.ac.ir
}

\begin{abstract}
Given the diversity of Iran Islamic architecture in various ceiling implementation, this trait is certainly rare in the. Domes' coverings are of glorious beauty in Imamzadehs. This research is based on descriptive-analytical approach. The data collection is done through a combination (library and field) approach. The study population in this article consists of 39 Imamzadehs in scope of Organization of Endowments and Charity Affairs in Damavand city in Tehran province. In this study, first the subjects about the dome and dome types are discussed. Then a table consisting of tombs' domes tombs in this city has been presented. Its main purpose, in addition to comparative studies, is to reach a theoretical basis for protection and restoration of monuments in Damavand city, and the importance of studying and doing research in traditional architectural structures of Iranian architecture for the continuity and sustainability of Iranian authentic art will be determined. According to the study results on the basis of the frequency distribution tables and charts, pyramidal domes in this city has been built the most.
\end{abstract}

Keywords: Dome, Rok dome, Minaret, Immamzadeh, Damavand (city)

\section{INTRODUCTION}

This paper aims to study 39 Imamzadehs in scope of Organization of Endowments and Charity Affairs in Damavand city in Tehran province, and its main task, in addition to comparative studies, is to reach a theoretical basis for protection and restoration. These buildings are located in East Tehran with mountainous climate area, and they refer to part of political and religious history of the region, particularly the AH 8th and 9th centuries. Normally in different periods, preservation and restoration of tombs was done to create a holiness for the people of the city or even further regions. Therefore, the tombs that were built for aristocrats or non-religious people became unpopular and less attention paid to them.

Most of the tombs in Iran were built during the AH 390 to 569 for princes, warriors and generals. Most of these places have quadrilateral, circle, etc. plan and are different in the type of appearance. Sometimes sharp arch domes, and sometimes in oval and flat ones were built over them. During the AH 9th century, simple tomb type in Damavand city became strongly popular. Thus, after this period, the tomb tower was rarely used. And it was replaced by Rok domes. (Raee, 2011, p. 76)

Various issues are effective in protecting the identity and creating social-emotional unity. Among these issues, religious buildings can play a major role as one of the places for identifying and promoting Islamic culture. And in this regard, the role of Imamzadehs in stabilizing the Islamic culture and attracting 
population and their status can be mentioned as a space to confluence ideas and expressions of religious beliefs. The importance and necessity of preserving ancient monuments, not only as symbolic phenomena, but also since understanding the evolution of urban history and urban civilization, protecting the identity and authenticity of the city and urban life are based on scientific evidence, it has always been of great importance. In Shia custom, Imamzadeh means the child or generation of Imams. And it is determined as of the location of the tomb and those who were scattered throughout the towns and villages in Iran. According to Muslim beliefs and their respect for these characters, Imamzadeh buildings are as places that have long been in charge of promoting urban and Islamic identity of citizens (Hejazi and Alizadeh, 2012). In this study we aim to the minarets and domes in Imamzadehs of Damavand, Tehran Province, and find out what type of dome is used more, and why? And Rok domes are discussed. Rok domes are studied due to their historical background and also due to the high number and diversity in the country. One of the characteristics with rok domes is that they can be recognized as tomb or the tomb tower usage; one of these usages is Imamzadeh's tomb.

\section{Dome:}

Geometric definition: The Dome is the locus of points which is formed by circulation around a vertical axis. In architecture: it is an architectural structure like a hollow hemisphere (Architect.Nemoneh.com).

In Pahlavi it is called Gumbat. The history of building domes with various materials is very long. Corbel domes can be seen in buildings and tombs in the ancient Middle East. The first advanced domes began in Europe and in Roman Architectural Revolution, when the Romans built temples and public buildings in large spaces, such as the Pantheon.

\section{Dome Structure:}

It has three parts: 1. Dome foundation, 2. Body where it is built in form of cube with one or two open sides (in pre-Islamic era, it had four opening sides), 3. Assembling, since in Persian architecture the ends are often in form of square and rectangular they make it circle to mount the dome. For this reason Assembling is important step in constructing a dome. Usually in buildings, in which they want to make a dome, they consider a square plan to simply make it into 8,16 and 32 and finally a circle. (Architect.Nemoneh.com)

\section{Dome History:}

Man from prehistoric to modern times made dome-shaped structures using available materials. Although it is unclear when the first dome was built, scattered examples of early domed structures were discovered. The discoveries of seal impressions in the ancient site of Chogha Mish (c. 6800 to 3000 BC), located in the Susiana plains of Iran, show the extensive use of dome structures in mud-brick and adobe buildings, likely granaries. Persian Sassanid architecture perhaps inherited Mesopotamia dome architecture. Ardashir Palace and Dokhtar castle ruins (Firozabad) in Fars province, by Ardashir I (224-240) shows the building of domes by Sassanid Empire (Figure 1, Figure 2 and Figure 3).

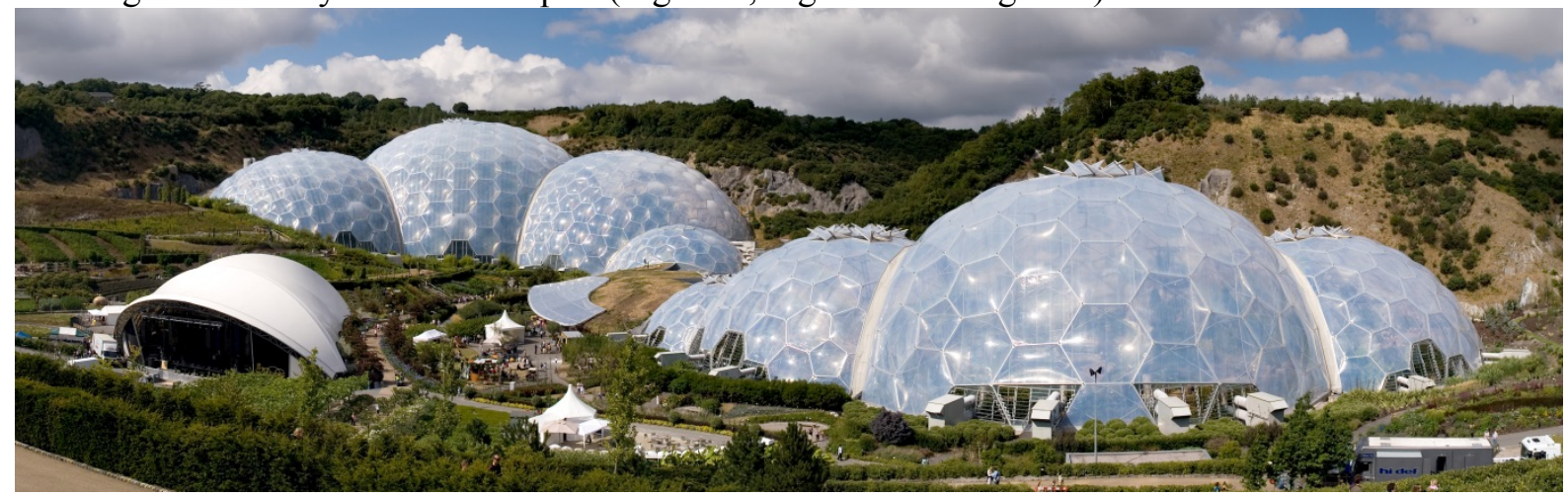



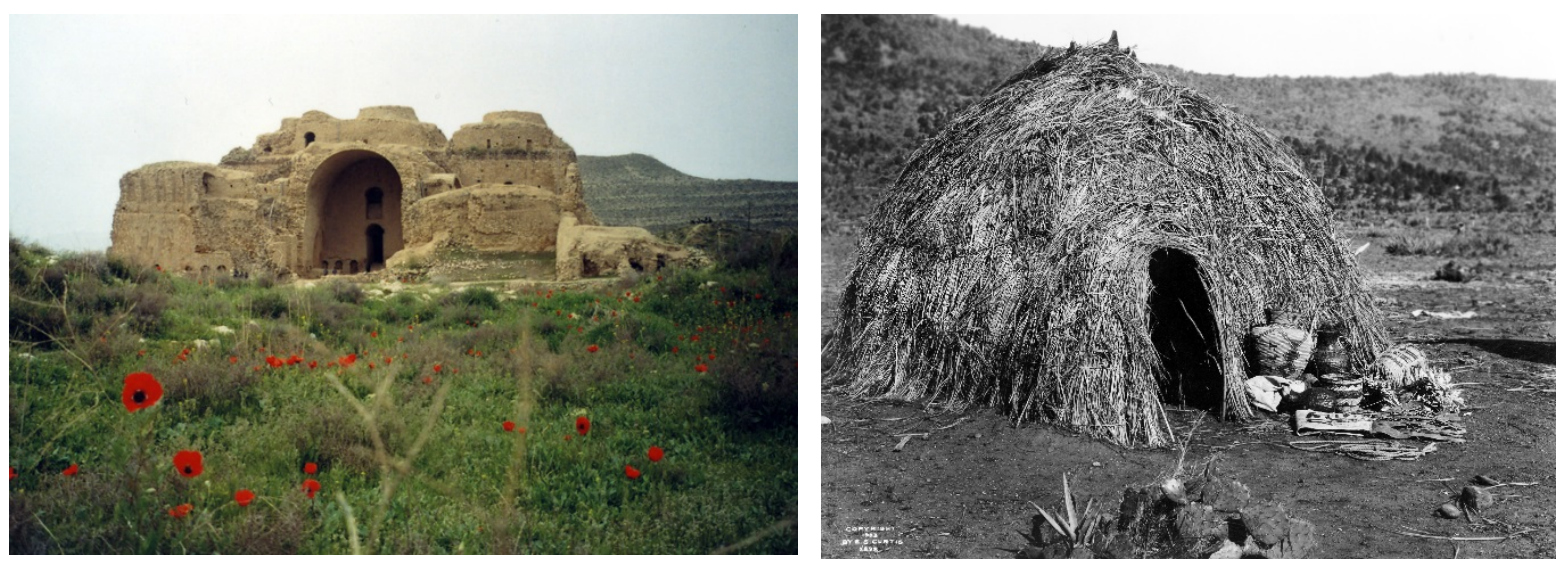

Fig 2. Ardashir Palace

Fig 3. Straw cottage.

\section{Dome Types:}

In areas like Rome hemisphere domes were more common. And since it could not match the curve, the edges need to be sharper. However, the Iranian architects considered semicircle unfit for cover, and shapes such as oval. So, the thickness of dome in the foundation was 1/16 of the crater (becomes thinner as it goes up) 1. onion dome. 2. Corbel dome. 3. Oval dome. 4. The Parabolic dome. 5. Polygonal dome. 6. Sail dome 7. Saucer dome. 8. Umbrella dome.

\section{Pirnia's Categorization of Domes:}

According to Professor Pirnia, the dome is divided into four groups in terms of the form. (Pirnia, 1987) 1) Nar Dome: The most common type of dome in Iran. This form is spherical dome. Iran's most important mosques such as Jame Mosque, Imam Mosque and the Mosque of Allah Varikhan in Isfahan and Yazd Mosque and Aghabozorg school and Kashan mosque has this form of ceiling. The dome of these mosques for had been built in form of two shells which are actually two domes on each other. In two shells domes of the shell, the upper side shell is for decoration and protecting from weather conditions and underside shell is as the weight holder. One of the reasons for using two shells in the dome is in terms of building scale in the city. Since large domes and high-rise buildings are a sign of importance, the scale of the domes must be determined in accordance with these factors, and preferably be seen from different parts of the city. Thus the dome are built with high height, but in order not to lose the harmony and as the hall under the dome is preferred not to seem like a vertical tunnel, the lower crust is lower in height.

Another reason is that the thickness of the lower dome $t$ to the tip of the dome is decreased to decrease the weight of the dome. That's the Dome cover is like stairs and to cover the unevenness, the second dome is made. The double-shelled dome is better in reducing heat exchange between the interior and exterior area of the dome, because relatively stagnant air between the two shells, is like an insulation that prevents heat exchange. But it should be noted that there should be no imprisoned space in the building, because due to humidity and moisture condensation at night or in cold weather, it turns into water, causing the deterioration of the material inside this space. So air conditioning should always be done between the two shells. (Qobadian, 2010, p. 137)

2) Rok Dome: Rok Dome is in pyramid or conical forms. (Pirnia, 1986), often placed on a cylindrical or prismatic pedestal. If the Dome material is brick, it is often double-shelled dome, to be proportional to the below scale, and have greater strength. (Qobadian, 2010, p. 140) 
1- Conical rok dome: This type of coating is also referred to Sugarloaf domes. This cross-sectional diameter of dome is equal to the back to the below pillars, and nowhere does not exceed the opening diameter. Tombs of Prince Ahmad in Lorestan and Imamzadeh Azhar in Hamedan are the examples. (Zomarshidi, 1988, p. 20)

2- Pyramid rok domes: in this dome cross-section is like a regular polygon and the end of the dome is sharp. Because of the height of the domes three covers are usually built, which are as follows:

(A) Lower coating that reduces the height of the space under the dome and is thermal-sound insulation.

(B) An intermediate coating between the lower and upper cover, and inhibits the dome.

(C) The upper cover which is made in form of a pyramid or cone. (Zomarshidi, 1988, p. 20)

\section{3) Embankment dome}

The third type is embankment dome, which is in pyramid form like rok dome. Surfaces in this dome, are not equal. A good examples are Mashhad Mir Bozorg dome in Amol which dates back to Shah Abbas Safavid era.

4) Pineapple Dome: which is in conical form in rok dome, it is similar to Pineapple. The dome is used only for tombs. Similar domes like this one has not been seen at any place and any book except in Iran and Iraq. In Iran, it is just in the southwest of the country. They are rare and therefore unique.

"The most famous dome, belongs to the tomb of Daniel in Susa. Other buildings with Pineapple Dome are tomb of Sarband and Laith in Dezful, Abdullah in Shushtar, Jafar Imamzadeh in Boroujerd, Mirmohamad Imamzadeh Kharg Island, tomb of Syed Salahuddin Muhammad in Abdanan (Ilam) and also the dome of the Sultan Zubaydah and the tomb of Sheikh Umar Suhrawardi in Baghdad. "(Qobadian, 2010, p. 137)
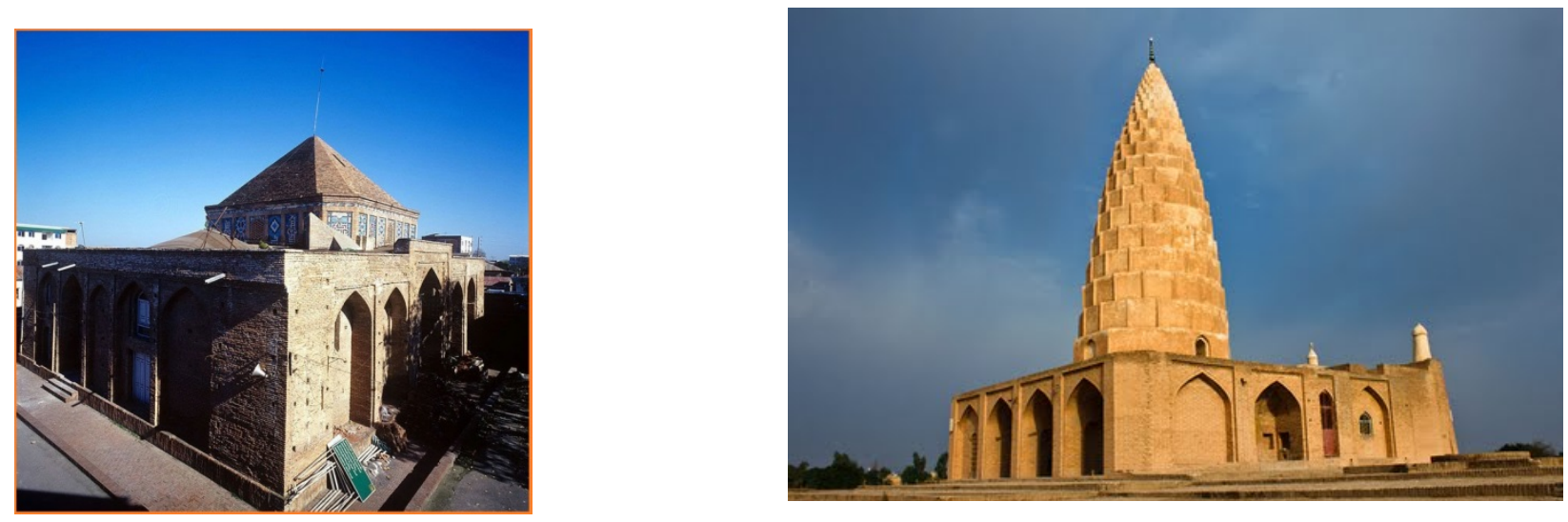

Mashhad Mir Bozorg dome in Amol

Daniel tomb in Susa

Dome during the Sassanid era:

Constructing a dome was so common in Sassanid era; from then until today domes are utilized as a pattern. Mathematical precision in determining the structure and the application were done; however, several developments have taken place since the early Islamic period. The method of constructing a dome in Iran has always pursued its own cultural characteristics and performance. It is noteworthy to mention that this feature as shape or no template makes it always different from oriental domes (Architect.Nemoneh.com).

\section{Various domes in Imamzadehs of Damavand based on Pirnia division}


Based on the division by Pirnia. Rok and nar domes are used in this city. Pineapple and embankment domes cannot be seen. Pyramid domes was more used than other domes.

(Table 1 and Chart 1)

Chart 1. Various domes in Imamzadehs of Damavand, Tehran Province

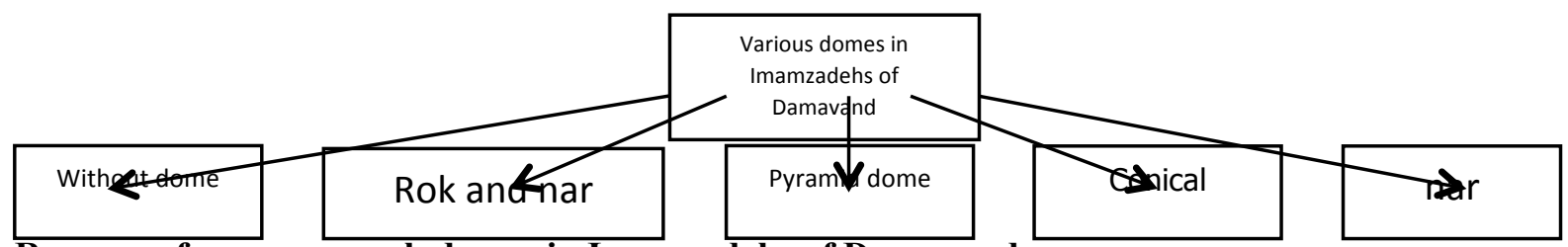

Reasons of numerous rok domes in Imamzadehs of Damavand

Rok domes on shores of Caspian Sea and mountain regions have been used. And it can be concluded that rok domes in these areas can be seen more than other parts of Iran.

1) This type of dome is better than nar dome in terms of climate, because it passes away rainfall faster and better than nar dome.

2) The dome is similar to sloped roofs of inhabitants in the region.

3) Has usage of tomb and mausoleum tower sign.

Minaret:

Minaret (minaret) is a circular tower that is one of the elements of Islamic architecture and is used in the mosque. There are five Imamzadehs in Damavand city which have minarets.

Apparently the word means the lamp base; lights for travelers since in Arab world travelers moved at night.

Three main applications of Minarets:

1. Guidance: to guide the caravan on the road and showing the main sites of the urban area.

2. Adhan and news: A place to call for a prayer.

3. Symbol of victory: this type of minarets were made from the skulls of humans and animals.

Four main components of Minarets:

1. The base or podium: in square shape or ambiguous that stem is located in the middle. Minarets' base in Khosrowgerd in Sabzevar and Rahrovan in Isfahan are square. And Gar, Sien and Ziar minarets are octagonal. Some of the minarets have no platforms such as Borsian minarets, or Ali and Sarban minarets.

2. Stem: Iran's pre-Islamic minarets are often square and in the Islamic era, they are cylindrical or conicalshaped.

3. Cap: square and octagonal.

4. Vertex: shading in various forms

Table 1. Domes in Imamzadehs of Damavand, Tehran Province. Source: authors 


\begin{tabular}{|c|c|c|c|c|c|c|}
\hline $\bar{\Xi}$ & $\begin{array}{l}\dot{\bar{d}} \\
\dot{0} \\
\bar{\Xi} \\
z\end{array}$ & 芯 & 矛 & 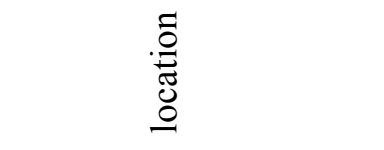 & $\begin{array}{l}\stackrel{\Xi}{\Xi} \\
\text { ż }\end{array}$ & 3 \\
\hline & 2 & $\begin{array}{l}\text { Nar } \\
\text { dome }\end{array}$ & $\begin{array}{l}\text { Safavid } \\
\text { era }\end{array}$ & $\begin{array}{l}55 \mathrm{~km} \text { North East of } \\
\text { Tehran (Haraz road) }\end{array}$ & $\begin{array}{l}\text { Hashem } \\
\text { Imamzad } \\
\text { eh (AS) }\end{array}$ & 1 \\
\hline & & $\begin{array}{l}\text { pyrami } \\
\text { d rok }\end{array}$ & $\begin{array}{l}\text { 7th and } \\
\text { 8th } \\
\text { centuri } \\
\text { es AH }\end{array}$ & $\begin{array}{l}40 \mathrm{~km} \text { within Tehran, } \\
\text { next to gas station, St. } \\
\text { Sajadian }\end{array}$ & $\begin{array}{l}\text { Mohamm } \\
\text { adtaghi } \\
\text { Imamzad } \\
\text { eh (AS) }\end{array}$ & 2 \\
\hline & & $\begin{array}{l}\text { conical } \\
\text { rok }\end{array}$ & $\begin{array}{c}200 \\
\text { years } \\
\text { ago }\end{array}$ & $\begin{array}{c}\text { Rudehen, } 14 \mathrm{~km} \text { within } \\
\text { Jordi village }\end{array}$ & $\begin{array}{c}\text { Jurd } \\
\text { Imamzad } \\
\text { eh (AS) }\end{array}$ & 3 \\
\hline & & Nar & $\begin{array}{l}\text { Safavid } \\
\text { era }\end{array}$ & $\begin{array}{l}40 \mathrm{~km} \text { Haraz road, } \\
\text { Creighton } \\
\text { neighborhood, the } \\
\text { Imam (Khomeini), } \\
\text { Southeast Heights }\end{array}$ & $\begin{array}{l}\text { Ibrahim } \\
\text { Imamzad } \\
\text { eh (AS) }\end{array}$ & 4 \\
\hline & & $\begin{array}{l}\text { pyrami } \\
\text { d rok }\end{array}$ & $\begin{array}{l}5 \text { th and } \\
6 \text { th } \\
\text { centuri } \\
\text { es AH }\end{array}$ & $\begin{array}{l}43 \mathrm{~km} \text { Tehran Haraz } \\
\text { road, between the } \\
\text { Mobarak abad and } \\
\text { hezardasht }\end{array}$ & $\begin{array}{l}\text { Hamze } \\
\text { Imamzad } \\
\text { eh (AS) }\end{array}$ & 5 \\
\hline
\end{tabular}




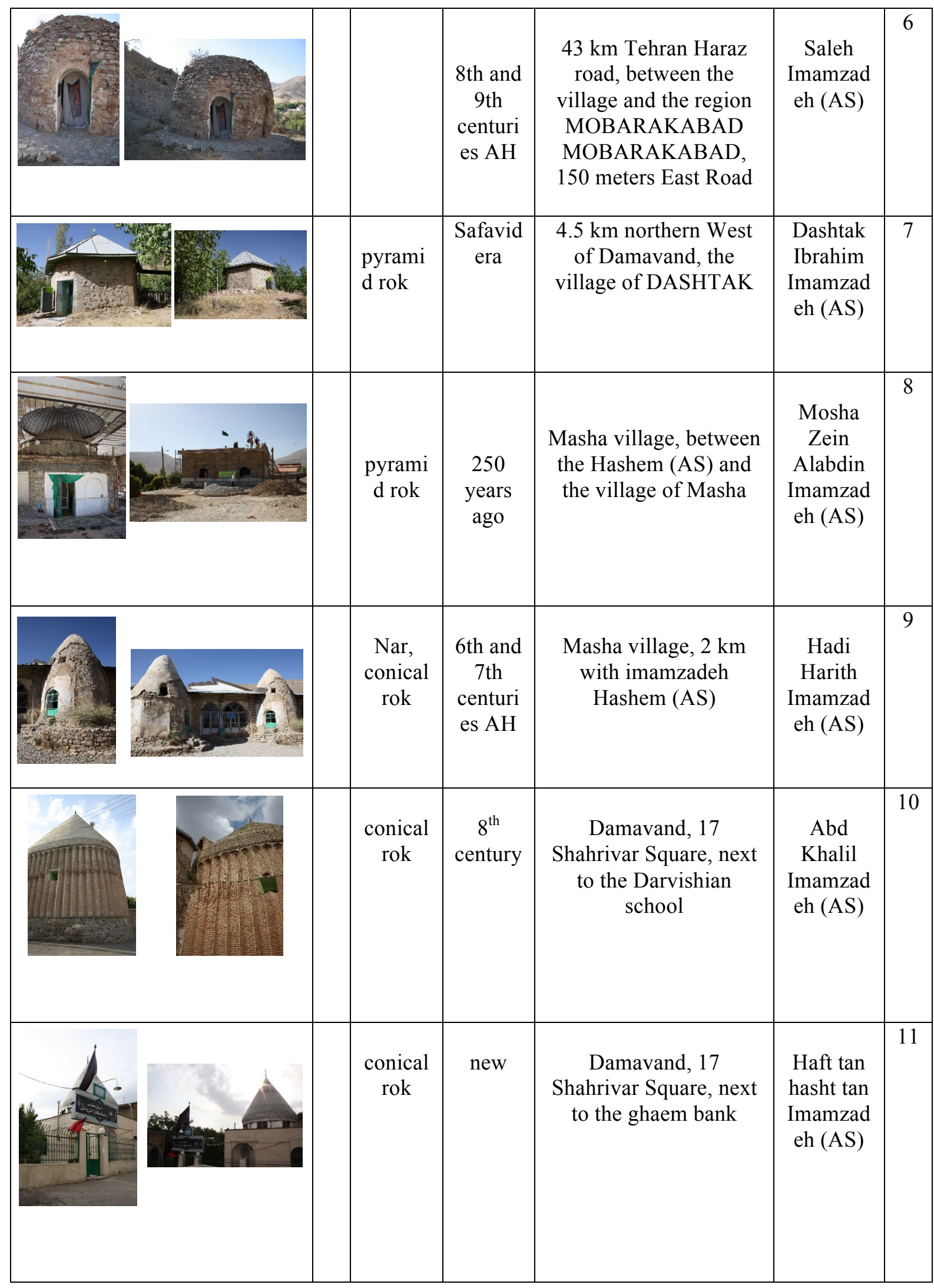




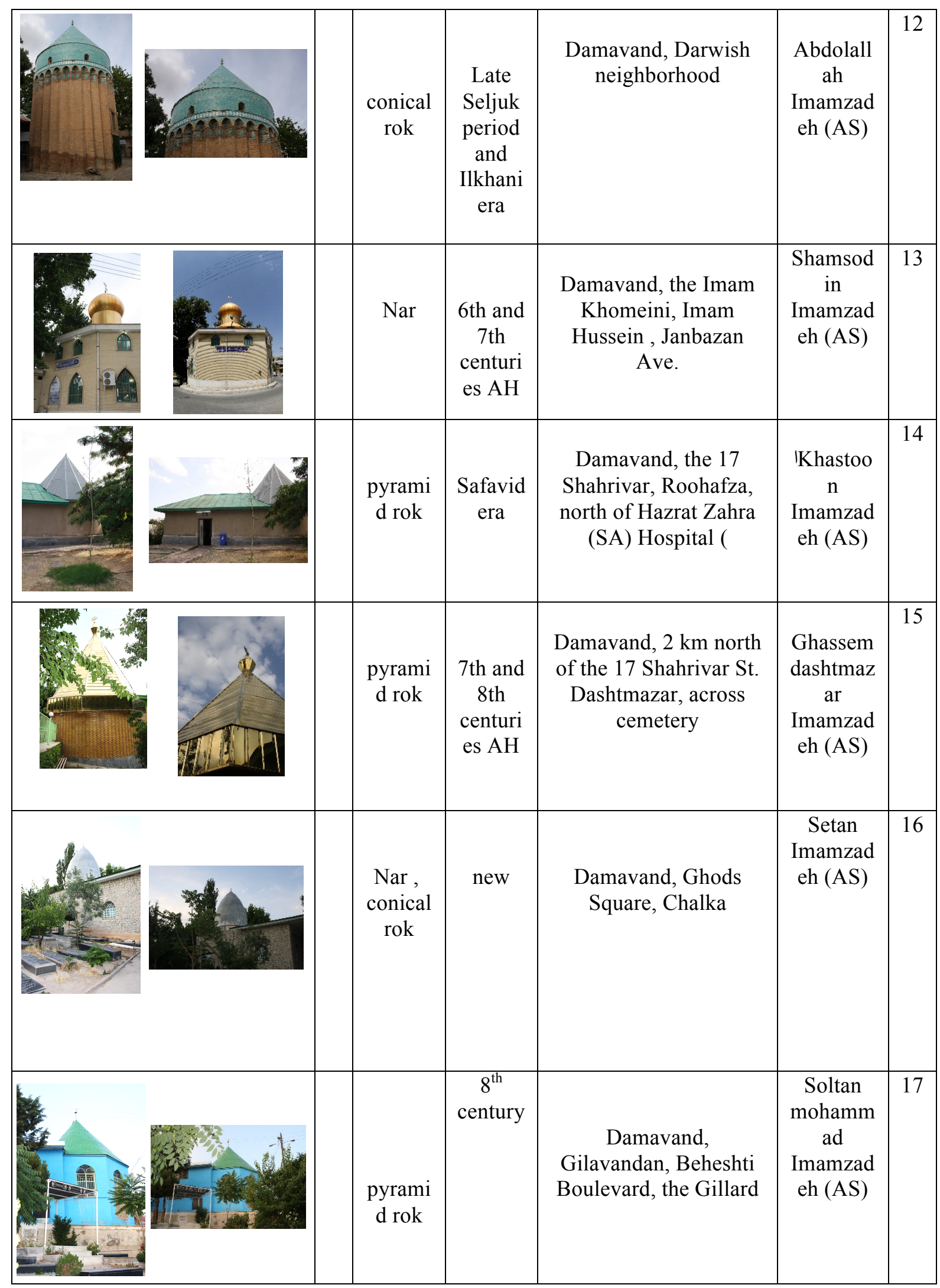

Submit Date: 01.05.2016, Acceptance Date: 20.06.2016, DOI NO: 10.7456/1060JSE/065

Copyright $($ T) The Turkish Online Journal of Design, Art and Communication 


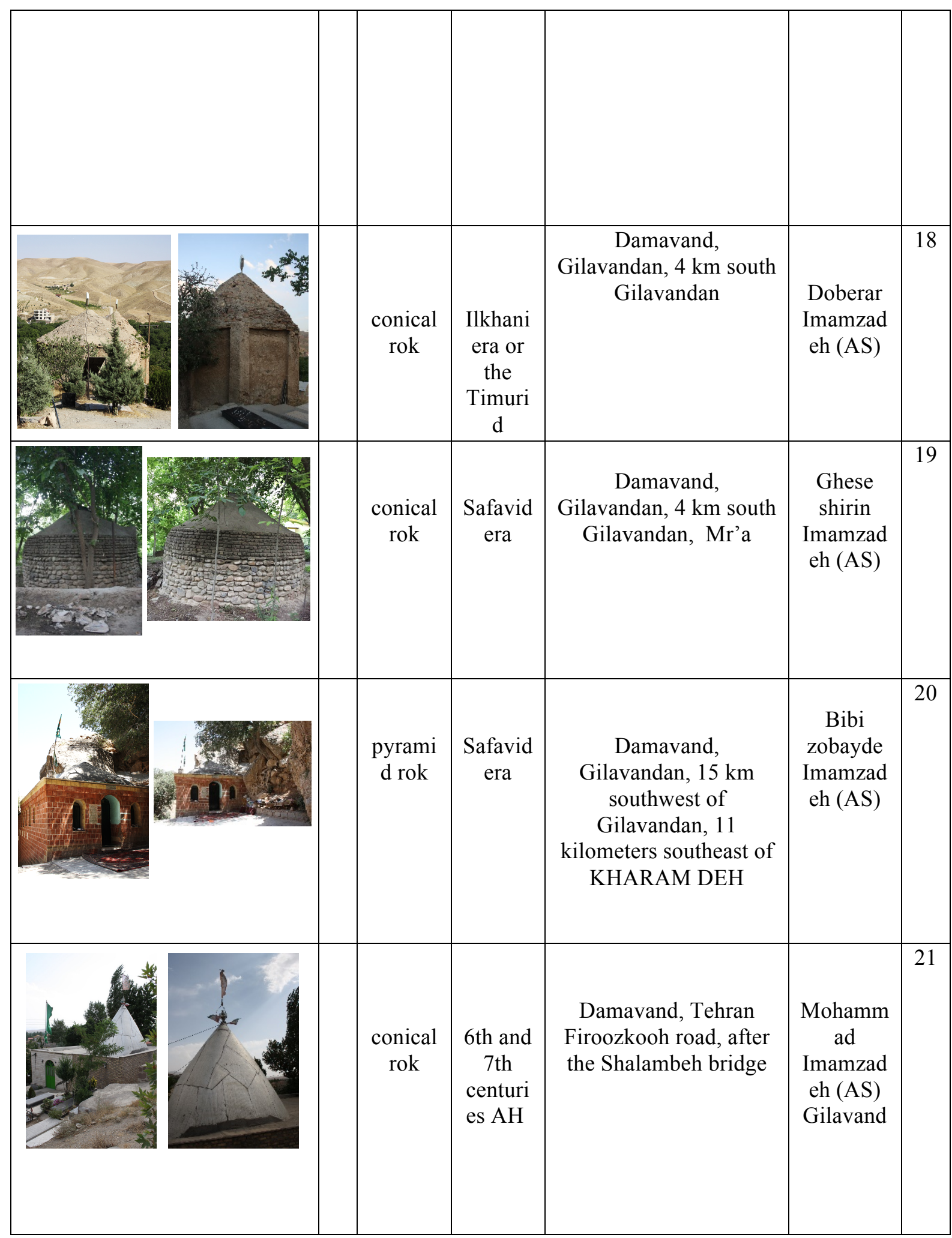




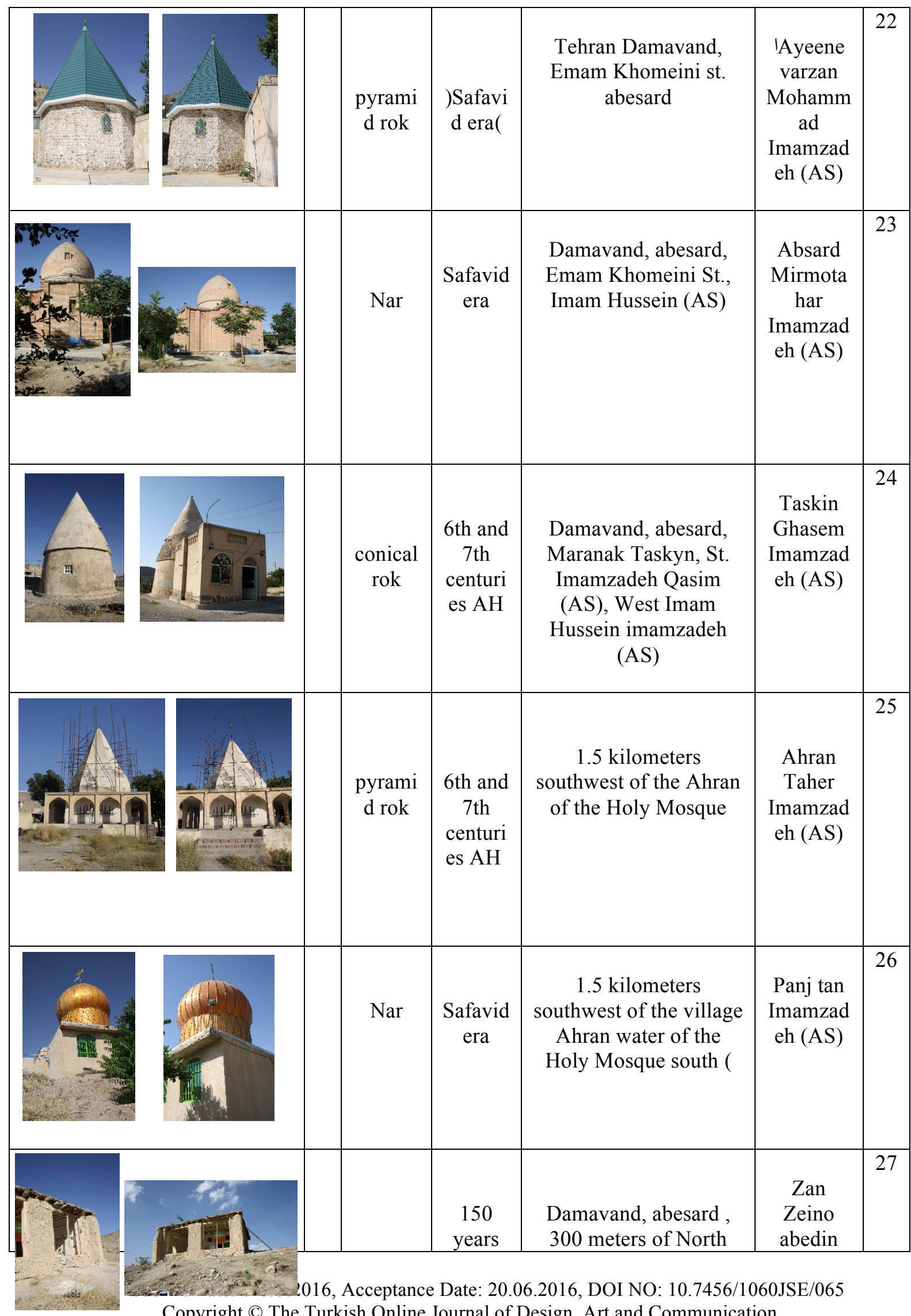

Copyright (C) The Turkish Online Journal of Design, Art and Communication 


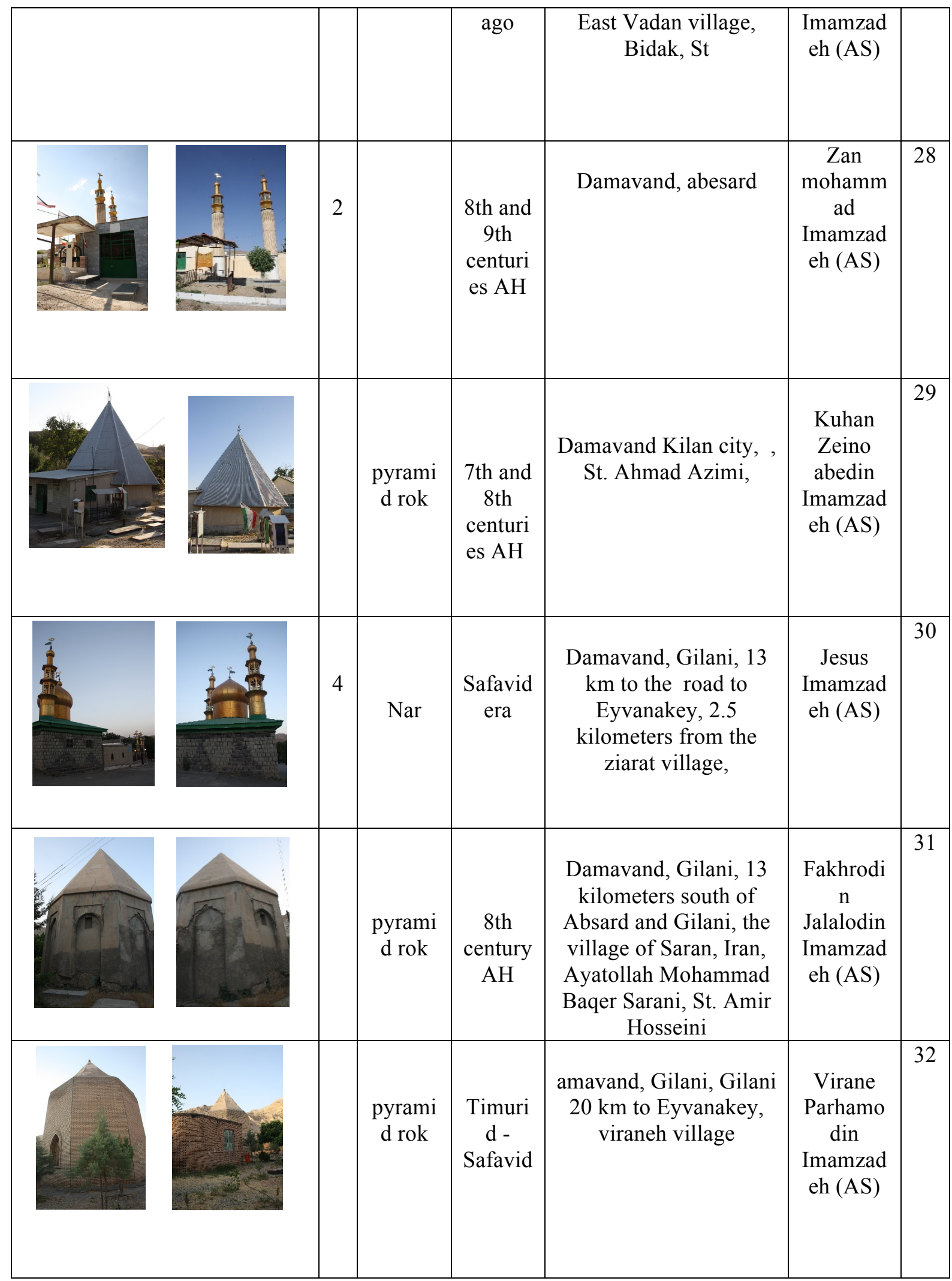




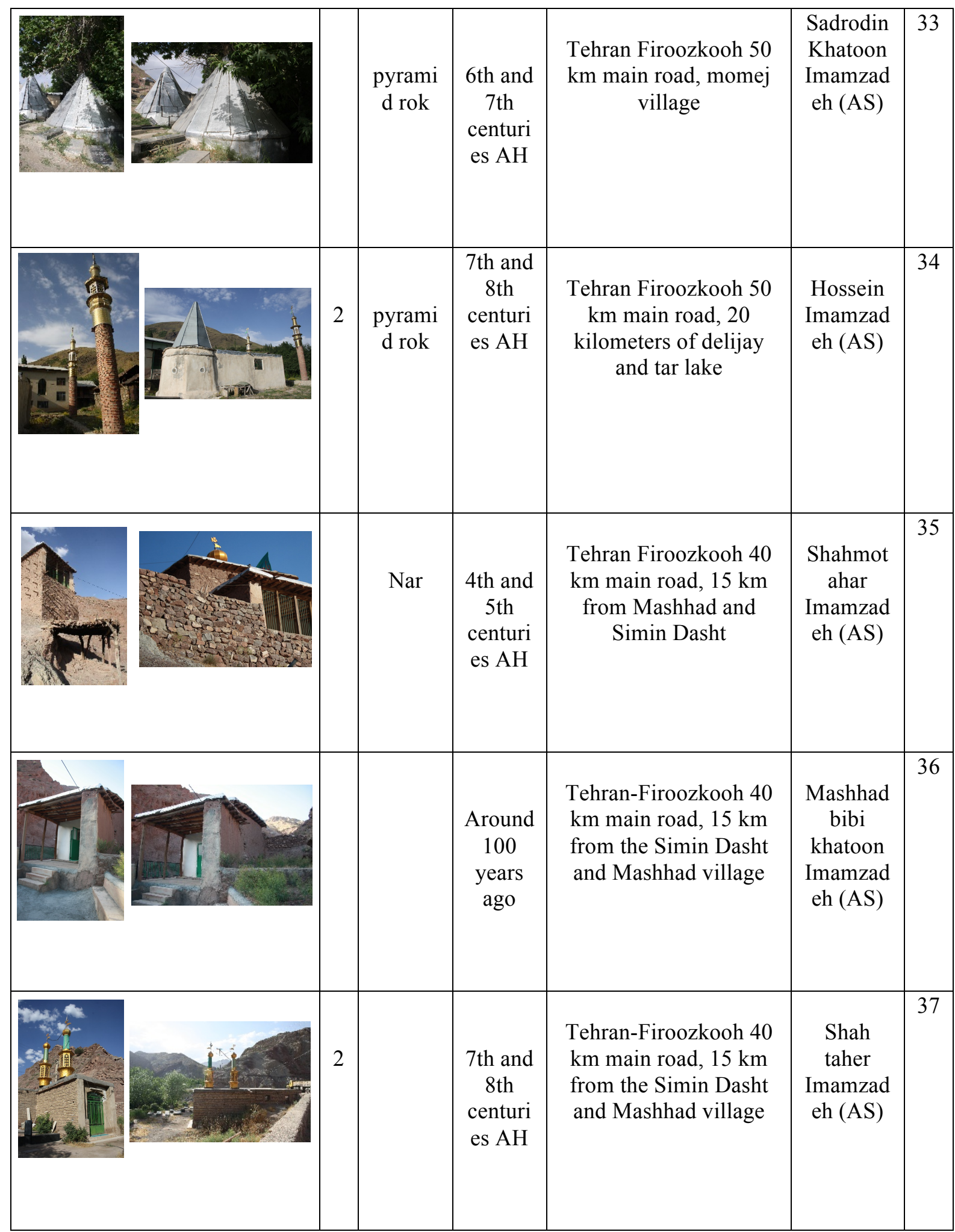




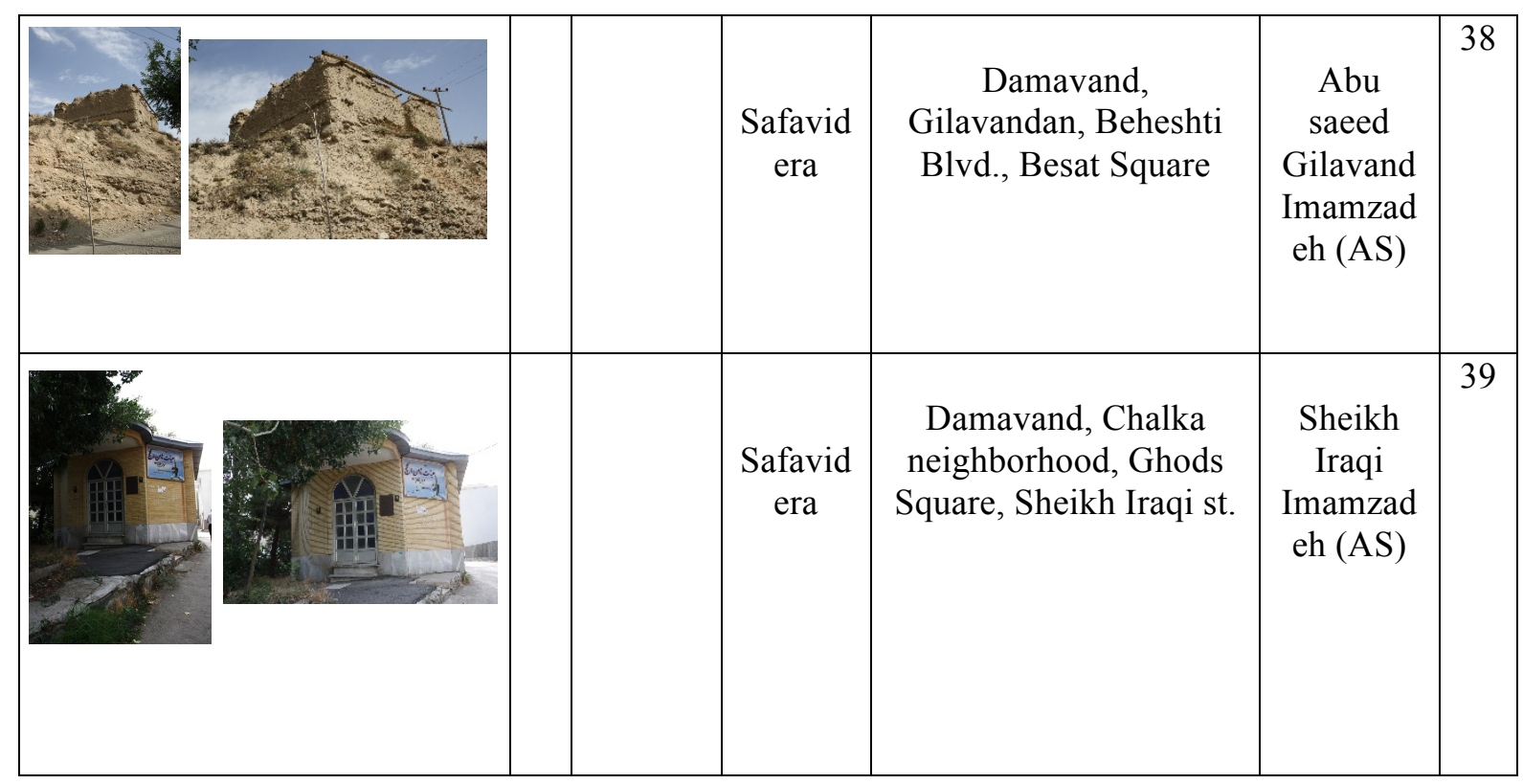

\section{CONCLUSION}

Finally, we can say that several things are effective in protecting the identity and creating unity such as moral and cultural values and historical monuments and national values. Also, it is clear that cultural identity and traditional features and values of a society are formed in the context of factors such as history, religion and their components. And reviewing the history and the influences of Islam and all the ups and downs in the history of Iran explains the relation between these two cultures. Some symbols are common in many cultures of the world. Sometimes these common symbols have the same referent; and this adds to the importance of them. Dome is among these symbols. Symbolic value of architecture in the dome structure is important. And that the meaning of life lies in its context. That can be regarded as the definition of the macrocosm and microcosm. Because this sense refers both to the world and man. Naturally, it is primarily true about the temples, religious monuments and tombs. So number of ontological approaches exists and relates to the views of the community and in any approaches a traditional architecture is born. Totally, attention to cultural values of Iran among Islamic countries and as Iran owns many monuments and architectures related to Islamic world, it is important to protect and restore the places to be reminded in tomorrow's world. According to the research the following results are obtained:

1. Based on the division by Pirnia. Rok and nar domes are used in this city. Pineapple and embankment domes cannot be seen.

2., in order of frequency and percentages the domes are as follows: pyramid dome: $14 \times 36 \%$, Conical Dome: $9 \mathrm{x}$ and 23\%; Nar dome: $7 \mathrm{x}$ and 18\% without dome: $7 \mathrm{x}$ and 18\%, Nar-pyramid: $2 \times 5 \%$. (Chart 2 and Chart 3)

3. Most of the domes are pyramid domes and the less seen domes are Nar-pyramid domes.

4. Seven Imamzadehs have Nar domes: 1 Hashem Imamzadeh (AS), 2. Ibrahim Imamzadeh, 3. Shamseddin Mohammad Imamzadeh, 4 Mirmotahar Imamzadeh (AS) 5. Panj-tan Imamzadeh, 6. Jesus Imamzadeh, 7. Shahmotahar Imamzadeh (AS).

5. There are two Nar-pyramid dome: 1. Imamzadeh Hadi and al-Harith, 2 Setan Imamzadeh (AS)

6. Seven Imamzadehs are without the dome: 1. Saleh Imamzadeh (AS) 2. Zine El Abidine Imamzadeh 3. Prophet Muhammad Imamzadeh, 4. Bibi Khatoon Imamzadeh, 5. Shah Tahir Imamzadeh (AS) 6. AbuSaeed Imamzadeh (AS), 7. Sheikh Iraqi Imamzadeh 
7. There are five Imamzadehs with minarets which have two minarets, except the Imamzadeh of Jesus (AS) which has four minarets. (1- Hashem Imamzadeh (AS), 2. Holy Prophet Muhammad Imamzadeh (S), 3. Hussein Imamzadeh, 4. Shah Tahir Imamzadeh

\section{REFERENCES}

Pirnia M.K., (1986). Tehran series of presentations in the office of the protection of antiquities.

Pirnia M.K., (1973). "Iran's dome architecture", art and people, year 12, No. 136-137.

Pirnia M.K., (2004). architecture style of Iran, Tehran, Soroush Danesh.

Pirnia M.K., (2006). Islamic architecture of Iran, Tehran, Soroush Danesh.

Hejazi and Alizade, (2012). " the spaces on preserving the Islamic identity of the Imamzadehs, Case Study of Mir Bozorg in Amol ", International Conference on Religion and Art, Hamadan.

Raee, H., (2011), "the study of shrines8th and 9th century AH in Mazandaran. Introducing the tomb of Shams al-Rasul in Amol", Journal of historical contexts, the first year. (2). Pages 75-89.

Zomarshidi, H., (1988). Arch in architecture, Tehran, Keyhan publishing.

Qobadian, V. (2013). Climate study of traditional buildings, Tehran University Press.

Ameli A.(1972), dome of mosques in Iran, the newspaper of world economy, 24 October 2011; quoted by Professor Pirnia.

Wilber, Donald, (1995). Architecture in Iran and Turan. Translation by Keramatollah Tafasor and Mohammad Kiani. Cultural Heritage Organization. Tehran, published by the Ministry of Culture and Islamic Guidance.

Youzbashi, A. (2015). Master thesis in visual communications, Faculty of Arts, Shahed University, Tehran.

Architect.Nemoneh.com 